\title{
Dopa-responsive dystonia and its diagnostic challenges: A case report
}

\author{
*Lasanthi Kumari Weerasooriya ${ }^{1}$, Jithangi Wanigasinghe ${ }^{2}$ \\ Sri Lanka Journal of Child Health, 2018; 47: 268-270 \\ DOI: http://dx.doi.org/10.4038/sljch.v47i3.8551 \\ (Key words: Dopa-responsive dystonia, Segawa syndrome)
}

\section{Introduction}

Dopa-responsive dystonia (DRD), also known as Segawa syndrome, is an inherited disorder characterised by diurnal fluctuations of dystonia and a highly favourable response to levodopa. The commonest type of DRD is DYT5 dystonia which has a dominant inheritance and is due to mutations in the GTP-CH1 gene located on 14q22.1-q22.2 $2^{1-3}$. The recessively inherited DRD frequently affects cognitive function ${ }^{1}$. A difference in ratio of mutant/wild-type GCH-I mRNA can explain phenotypical variations ${ }^{4}$. DRD is often inadequately recognised, and often erroneously diagnosed as dystonic cerebral palsy or familial spastic paraparesis. We report a child with DRD.

\section{Case report}

A 7 year old girl presented with progressive difficulty in walking and frequent falls for 4 years. Her symptoms aggravated towards evening and she felt better in the morning. During occasional afternoons she was completely unable to walk without support. These fluctuations were not related to illness or medications. She did not complain of generalized body weakness, difficulty in speech or swallowing. Her antenatal, intrapartum, and neonatal periods were uneventful. There was no developmental delay, regression or arrest noted. There was no family history of similar illness.

Her higher functions (learning ability, memory, orientation, attention span, insight etc.) were not altered. Her speech was hypophonic. She had an abnormal gait characterized by stiff legs and a tendency to walk in a tip toe gait, resulting in difficulty in maintaining balance. The muscle tone was increased only slightly in the upper limbs in comparison to significant increase in the lower limbs. Power in upper limbs was normal but $4 / 5$ in

\footnotetext{
$\overline{{ }^{1} \text { Lady Ridgeway Hospital for Children, Colombo }}$, Sri Lanka, ${ }^{2}$ Department of Paediatrics, Faculty of Medicine, University of Colombo, Sri Lanka

*Correspondence: weerasooriya.lk@gmail.com

(Received on 18 January 2017: Accepted after revision on 20 February 2017)

The authors declare that there are no conflicts of interest

Personal funding was used for the project.

Open Access Article published under the Creative
}

the lower limbs. Postural tremor and dystonia were noticed on attempted movements of the upper limbs. Deep tendon reflexes were normal in upper limbs but increased in lower limbs with positive Babinski reflexes. Ankle clonus was present. The sensory system and cranial nerve examination were normal. Intention tremor was noted in both hands but other cerebellar signs were absent.

The peripheral blood smear revealed normal cell morphology. Liver functions and serum caeruloplasmin were within normal ranges. Slit lamp evaluation for Kayser Fleischer ring was negative. Anti-nuclear antibodies were negative and inflammatory markers were within the normal range. Magnetic resonance imaging (MRI) of brain and spine was normal.

In view of the typical diurnal variation of dystonia and the clinical picture, a therapeutic challenge with levodopa (syndopa \& carbidopa) was tried and there was a dramatic reduction in dystonia within two days and the child's gait improved. Based on supportive clinical features and excellent response to levodopa, a diagnosis of DRD was made. This was clinically confirmed by observing recurrence of her symptoms when the treatment was withheld. During follow-up, the child showed persistent clinical improvement while on treatment with levodopa.

\section{Discussion}

The initial description of DRD was by Segawa in 1971 in a group of children who had progressive dystonia which showed diurnal fluctuation and marked clinical response to levodopa ${ }^{5}$. DRD can manifest throughout childhood (range 9 months to 16 years). However, adults with the disease have also been reported. Females are affected more commonly than males. It is likely to be misdiagnosed as cerebral palsy due to similarities in clinical presentation ${ }^{6}$.

The presenting feature is always a gait disturbance manifesting as dystonic legs. This dystonia is progressive and more pronounced in lower than upper limbs. Dystonia can also affect the neck and axial musculature as well. DRD should be considered a possibility in any child presenting with a dystonic gait. Around $30-50 \%$ of patients with DRD have no family history ${ }^{7}$. 
A diagnosis of Segawa syndrome in the past was made based upon a thorough clinical evaluation and documenting a response to therapy with low doses of levodopa as a diagnostic test. The majority responds promptly to 50 to $100 \mathrm{mg}$ of levodopa, with dramatic relief from the dystonia and thus improvement in the gait ${ }^{8}$.

An oral phenylalanine loading test may detect only about $80 \%$ of cases of DRD. Investigations characteristically experienced in DRD include low levels of pteridine metabolites in the cerebrospinal fluid, normal neuroimaging, and increased blood phenylalanine levels after the phenylalanine loading test ${ }^{9}$. Polysomnography shows a reduction of approximately $20 \%$ of normal twitch movements during REM sleep ${ }^{10}$. The general trend in settings with resources is to confirm the diagnosis by testing for the DRD genetic panel. A therapeutic trial with L-dopa should be done in all patients suspected of having DRD. Fluctuations in response, increased dose requirements, or long-term adverse effects have not been noted ${ }^{11}$.

As these patients have selective striatonigral dopamine deficiency the natural history of the illness is gradual progression of the symptoms if left untreated $^{12,13}$. There are reported cases where, if left untreated, they may develop severe contractures and motor disability due to severe dystonia ${ }^{12,13}$. However, no data are available on mortality related to DRD. Patients with good responses to levodopa typically continue to have a stable course without long-term adverse effects ${ }^{14}$.

Authors intend to highlight that DRD should be thought of in any child presenting with paroxysmal or progressive hypertonia where the aetiology is not known. We also emphasize the importance of a trial of levodopa in all such patients. Detecting the specific mutation is of importance in confirming the diagnosis and facilitating genetic counselling.

\section{References}

1. Maita N, Hatakeyama K, Okada K, Hakoshima T. Structural basis of biopterininduced inhibition of GTP cyclohydrolase I by GFRP, its feedback regulatory protein. Journal of Biological Chemistry 2004; 279(49):51534-40.

https://doi.org/10.1074/jbc.M409440200

PMid: 15448133

2. Segawa $M$, Nomura $Y$, Nishiyama $N$. Autosomal dominant guanosine triphosphate cyclohydrolase I deficiency (Segawa disease). Annals of Neurology 2003; 54:S32-45. https://doi.org/10.1002/ana.10630

PMid: 12891652

3. Segawa M. Hereditary progressive dystonia with marked diurnal fluctuation. Brain Development 2000; 22 (Suppl 1): S65-S80.

https://doi.org/10.1016/S03877604(00)001 48-0

4. Hahn H, Trant MR, Brownstein MJ, Harper RA, Milstien S, Butler IJ. Neurologic and psychiatric manifestations in a family with a mutation in exon 2 of the guanosine triphosphate-cyclohydrolase gene. Archives of Neurology 2001; 58:749-55. https://doi.org/10.1001/archneur.58.5.749 PMid: 11346370

5. Deonna T. DOPA-sensitive progressive dystonia of childhood with fluctuations of symptoms--Segawa syndrome and possible variants. Results of a collaborative study of the European Federation of Child Neurology Societies (EFCNS). Neuropediatrics 1986; 17(2):81-5. https://doi.org/10.1055/s-2008-1052506 PMid: 3724992

6. Lee JH, Ki CS, Kim DS, Cho JW, Park KP, Kim S. Dopa-responsive dystonia with a novel initiation codon mutation in the GCH1 gene misdiagnosed as cerebral palsy. Journal of Korean Medical Science 2011; 26:1244-6.

https://doi.org/10.3346/jkms.2011.26.9.12 44

PMid: 21935284 PMCid: PMC3172666

7. Bandmann O, Nygaard TG, Surtees R, Marsden CD, Wood NW, Harding AE. Dopa-responsive dystonia in British patients: new mutations of the GTPcyclohydrolase I gene and evidence for genetic heterogeneity. Human Molecular Genetics 1996; 5(3):403-6.

https://doi.org/10.1093/hmg/5.3.403

PMid: 8852666

8. Venna N, Sims KB, Grant PE. Case 262006: a 19-year-old woman with difficulty walking. New England Journal of Medicine 2006; 355: 831-9. https://doi.org/10.1056/NEJMcpc069015 PMid: 16928999

9. Opladen T, Okun JG, Burgard P, Blau N, Hoffmann GFJ. Phenylalanine loading in paediatric patients with dopa-responsive dystonia: revised test protocol and 
paediatric cut-off values. Journal of Inherited Metabolic Disease 2010; 33(6):697-703.

https://doi.org/10.1007/s10545-010-91649

PMid: 20668943

10. Segawa M, Nomura Y. Hereditary progressive dystonia with marked diurnal fluctuation. Pathophysiological importance of the age of onset. Advances in Neurology 1993; 60:568-76.

PMid: 8420193

11. Steinberger D, Korinthenberg R, Topka H, Berghauser M, Wedde R, Muller U. Doparesponsive dystonia: mutation analysis of GCH1 and analysis of therapeutic doses of L-dopa. Neurology 2000; 55:1735-7. https://doi.org/10.1212/WNL.55.11.1735

PMid: 11113234

12. Fink JK, Ranin PD, Fillinh-katz M, Argoff CE, Hallett M. Clinical and genetic analysis of progressive dystonia with diurnal variation. Archives of Neurology 1991; 48(9):908-11.

https://doi.org/10.1001/archneur.1991.005 30210034019

PMid: 1953413
13. Nygaard TG1, Marsden CD, Fahn S. Doparesponsive dystonia: long-term treatment response and prognosis. Neurology 1991; 41(2 (Pt 1)):174-81.

PMid: 1899474

14. Furukawa Y, Guttman M, Nakamura S, Kish SJ. Dopa-responsive dystonia. In: Frucht SJ, ed. Movement Disorder Emergencies: Diagnosis and Treatment. 2nd ed. New York: Springer (Humana Press);

https://doi.org/10.1007/978-1-60761-8355_24 